\title{
Does psychological empowerment and perceived organizational support influence organizational citizenship behavior in the pharmaceutical industry? Affective organizational commitment
}

\section{as a mediator}

\author{
A.S. Usada \& R. Rachmawati \\ Faculty of Economic and Business Universitas Indonesia, DKI Jakarta, Indonesia
}

\begin{abstract}
The objective of this paper is to examine the relationship among psychological empowerment (PE), perceived organizational support (POS), and organizational citizenship behavior (OCB), while considering the mediating factor of affective organizational commitment (AOC) in the pharmaceutical industry in Indonesia. By employing a convenience sampling method with the help of a cross-sectional online survey, the data were collected from 270 employees working in pharmaceutical industries. SPSS, structural equation model, and LISREL were used for statistical analysis. The result of the study strongly supported the relationship among PE, POS, and AOC. However, an insignificant relationship was found between POS and OCB. The results also reported a significant relationship between $\mathrm{AOC}$ and $\mathrm{OCB}$ and between $\mathrm{PE}$ and OCB. Moreover, the relationship between POS and OCB was found to be mediated by AOC. These results help pharmaceutical industries to develop strategies to increase OCB in their company.
\end{abstract}

\section{INTRODUCTION}

In early 2020, Covid-19 spread throughout the world, including Indonesia (WHO, 2020). Many sectors were affected by the pandemic. One of the affected sectors is the pharmaceutical industry. To meet the needs of public health, the government (the Ministry of Industry) encourages the pharmaceutical industries to improve their performance. (Hakim, 2020). This affects employees who work in the industry. They should give an excellent performance to increase the effectiveness of the organization. To achieve effectiveness, it is necessary to improve the quality of human resources by building the desired character of organizational behavior and reflecting good citizenship. A previous study showed there are several factors affecting organizational citizenship behavior, such as affective organizational commitment (AOC), psychological empowerment (PE), and perceived organizational support (POS). The objective of this study was to examine structural relationships among PE, POS, AOC, and OCB in pharmaceutical industries.

\section{LITERATURE REVIEW}

Organizational citizenship behavior is an attitude of employees that aims to contribute more to the company or organization outside of their role (Bateman \& Organ, 1983). In 1994, Organ stated that OCB is a behavior exhibited by organization members without being given any compensation if they do work sincerely and sanctions if they do not do the work. The work is done without prior direction given and listed in the job description. Chen and Francesco (2003) argued that affective commitment has a positive effect on performance and OCB. The increasing affective commitment 
will also increase OCB from employees. Affective commitment plays the role of a mediator in the relationship between POS and OCB (Gaudet and Tremblay, 2017). Employees who possess a high POS level will be more committed to their organization and motivated to contribute to the organization to achieve its goals.

Affective commitment can also be the mediator for the relationship between PE and OCB (Srivastava et al, 2016). Affective commitment not only improves OCB, but is also one of the consequences of psychological empowerment felt by employees in their workplace. Employees with a high PE level will increase their affective commitment and motivation to give their best to achieve the organization's goals.

\section{RESEARCH METHODOLOGY}

This study is a quantitative research. The respondents were employees who worked in the pharmaceutical industries in all provinces throughout Indonesia. The data were collected using online questionnaires. The questionnaire required respondents to rate the importance of each statement on a 6-point Likert scale. To measure the psychological empowerment, this study used 12 questions that were adopted from Spreitzer (1995). To measure the perceived organizational support measurement, this study used 8 questions that were adopted from the Rhoades and Eisenberger (2001) research study. The AOC was measured by using 8 questions generated from the research done by Allen and Meyer (1990). Lastly, to measure the OCB, this study used 24 questions obtained from the research conducted by Podsakoff et al. (1990). The collected data were then processed using the SEM method with the help of the LISREL application.

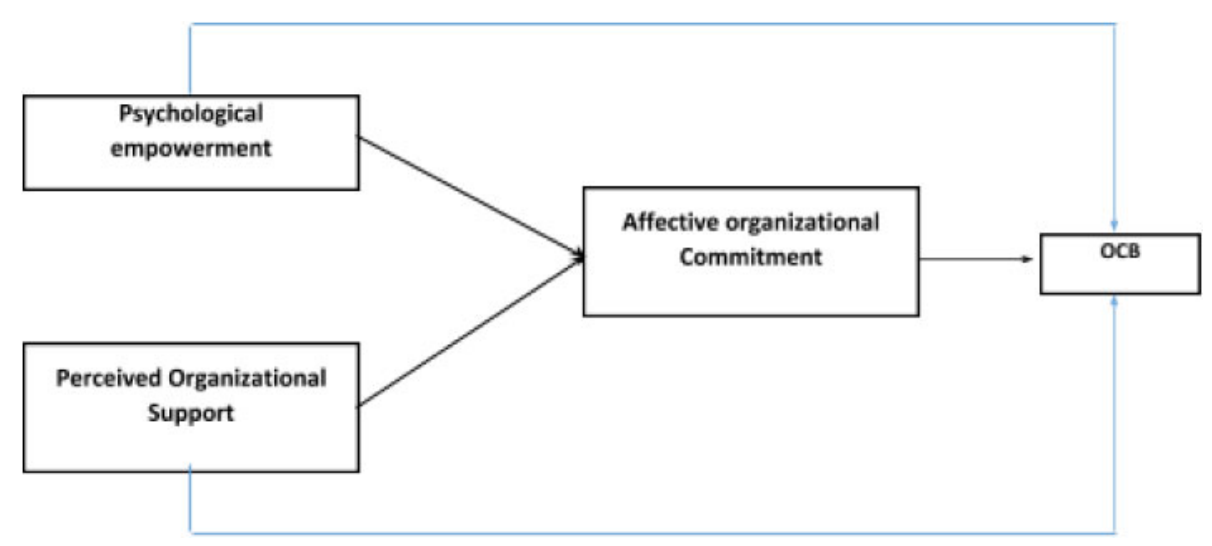

Figure 1. Research model

\section{RESULT}

\subsection{Descriptive}

The results of the survey showed that there were 109 (40,37\%) male employees and $161(59,63 \%)$ female employees from the 270 questionnaires distributed. The majority of the respondents belonged to the $21-30$ years age group $(77.78 \%)$. Almost $56.30 \%$ of respondents work in the national private sector; $27,40 \%$ work in the foreign private sector; and $16,30 \%$ work in state-owned enterprises. 


\subsection{Validity and reliability test}

Most of the indicators were valid. However, two indicators of OCB fell below the desirable cutoff of SLF; thus, they were omitted. The reliability test showed that the CR value of all dimensions/ variables was above 0.7 , and the AVE value of all dimensions/variables was more than 0.5 . This shows that all of the dimensions/variables used are reliable.

\subsection{The structural model}

Based on the structural models, this study has seven good fit indexes (RMSEA, ECVI, NNFI, NFI, RFI, IFI, and CFI). The hypothesis test was carried out to determine the influence among the variables used-psychological empowerment (PE), perceived organizational support (POS), affective organizational commitment (AOC), and organizational citizenship behavior (OCB). The estimation results of the overall model based on the SLF and T-values can be seen in the following table:

Table 1. Path diagram results for the structural model.

\begin{tabular}{|c|c|c|c|c|}
\hline Path & SLF & T-value & & Conclusion \\
\hline $\mathrm{PE} \rightarrow \mathrm{OCB}$ & 0.33 & 4.06 & & Hypothesis is accepted \\
\hline $\mathrm{POS} \rightarrow \mathrm{OCB}$ & 0.06 & 0.64 & & Hypothesis is rejected \\
\hline $\mathrm{PE} \rightarrow \mathrm{AOC}$ & 0.33 & 5.70 & & Hypothesis is accepted \\
\hline $\mathrm{POS} \rightarrow \mathrm{AOC}$ & 0.64 & 9.56 & & Hypothesis is accepted \\
\hline $\mathrm{AOC} \rightarrow \mathrm{OCB}$ & 0.39 & 3.23 & & Hypothesis is accepted \\
\hline \multirow[t]{2}{*}{ Path } & \multirow[t]{2}{*}{ Direct effect } & \multicolumn{2}{|l|}{ Indirect effect } & \multirow[t]{2}{*}{ Conclusion } \\
\hline & & a & B & \\
\hline $\mathrm{PE} \rightarrow \mathrm{AOC} \rightarrow \mathrm{OCB}$ & $\begin{array}{l}\mathrm{PE} \rightarrow \text { OCB } \\
\text { t-value: } 4.06 \\
\text { (Supported) }\end{array}$ & $\begin{array}{l}\mathrm{PE} \rightarrow \text { AOC } \\
\text { t-value: } 5.70 \\
\text { (Supported) }\end{array}$ & $\begin{array}{l}\text { AOC } \rightarrow \text { OCB } \\
\text { t-value: } 3.23 \\
\text { (Supported) }\end{array}$ & $\begin{array}{l}\text { Complementary } \\
\text { Mediation } \\
\text { Indirect only }\end{array}$ \\
\hline $\mathrm{POS} \rightarrow \mathrm{AOC} \rightarrow \mathrm{OCB}$ & $\begin{array}{l}\mathrm{POS} \rightarrow \text { OCB } \\
\text { t-value: } 0.64 \\
\text { supported) }\end{array}$ & $\begin{array}{l}\text { POS } \rightarrow \text { AOC } \\
\text { t-value: } 9.56 \\
\text { (Supported) }\end{array}$ & $\begin{array}{l}\text { AOC } \rightarrow \text { OCB } \\
\text { t-value: } 3.23 \\
\text { (Supported) }\end{array}$ & mediation \\
\hline
\end{tabular}

Source: Result of statistical data using LISREL

The results of the model testing had several outputs. When viewed from the results of the hypothesis test, there is one hypothesis that is rejected. It shows that perceived organizational support has no direct effect on OCB. However, in hypothesis 6, the results show that the effect of POS on OCB must be mediated by an affective organizational commitment. These results are in line with research conducted by Gaudet and Tremblay (2017), which shows that the POS variable will have an effect on OCB if it is mediated by AOC. Furthermore, the results proved that PE was found to have a positive effect on OCB. The results are in line with previous research conducted by Jha (2014), which states that PE had a positive and significant effect on OCB. His study also showed that AOC mediated the relationship between PE and OCB. These results indicate that someone who has a high psychological empowerment level can increase his/her involvement to perform extra roles in the organization. When employees are confident in doing their own work, they will be happy to do additional roles in their organization. An employee who has a high PE level will also influence their perception of commitment to their organization, which of course, will provide many benefits for the organization.

The idea that POS increases employee involvement in OCB behavior is not supported in this study. Therefore, even though management increases the level of POS in the company, it does not guarantee that these employees will be involved in OCB. The fact is that POS is not proven to 
directly increase OCB, but the effect of POS can be increased by adding affective commitment to OCB. An employee who is noticed by the company for his/her good behavior will increase his/her emotional attachment, which in turn will ensure that he/she will engage in OCB behavior.

\section{CONCLUSION AND SUGGESTION}

This study contributes to the understanding of the factors that influence OCB by examining the role of POS and PE on affective commitment. The results of this study suggest that someone who is trusted by the company will get a welfare and strong affective commitment to the company and thereby influence their OCB behavior.

Pharmaceutical industries can increase the OCB of their employees by giving their employees confidence, because of which they will have a strong influence on their work results. Furthermore, pharmaceutical industries can also give them a strong sense of belonging by conducting open and encouraging discussions between employees and management.

To increase the affective commitment of an employee, the company should give attention to its employees. The company must also respect the values and goals of each individual by being fair to all employees. The fair attitude can be demonstrated by not discriminating between each employee in the distribution of resources and opportunities to attend training held by the company.

\section{REFERENCES}

Allen,N.J., \& Meyer, J.P. (1990). The measurement and antecedents of affective, continuance, and normative commitment to the organization. Journal of Occupational Psychology. 63,1-18

Bateman, T.S., \& Organ, D.W. (1983). Job satisfaction and the good soldier: the relationship between affect and employee "citizenship". Academy of Management Journal. 26(1),587-595

Chen, Z.X and Francesco, A.M. (2003). The relationship between the three components of commitment and employee performance in China. Journal of Vocational Behavior, 62(3), 490-510

Gaudet, M.C., \& Tremblay, M. (2017). Initiating structure leadership and employee behaviour: The role of perceived organizational support, affective commitment and leader-member exchange. European Management Journal. 35(2017), 663-675

Hakim, R.N. (2020). Hadapi Pandemi Covid-19, ketua DPR Ingatkan Pemerintah benahi Sektor Kesehatan Nasional. https://nasional.kompas.com/read/2020/06/30/16180461/hadapi-pandemi-covid-19- ketua-dpringatkan-pemerintah-benahi-sektor

Jha, S. (2014). Transformational leadership and psychological empowerment: Determinants of organizational citizenship behaviour. South Asian Journal of Global Business Research. 3(1)

Podsakoff et al. (2000). Organizational citizenship behaviour: A critical review of the theoretical and empirical literature and suggestions for future research. Journal of Management. 26(3),513-563

Rhoades, L., Eisenberger, R., \& Armeli, S. (2001). Affective commitment to the organization: The contribution of perceived organizational support. Journal of Applied Psychology. 86(5),825-836

Spreitzer, G.M. (1995). Taking Stock: A Review of More Than Twenty Years of Research on Empowerment at Work. The Handbook of Organizational Behaviour. Cooper and Bariling (Eds.). Sage Publication Srivastava, A.P. and Dhar, R.L. (2016). Impact of leader member exchange, himan resource management practices and psychological empowerment on exta role performance: The mediating role of organizational commitment. International Journal of Productivity and Performance Management. 65(3),351-377

WHO (2020). WHO Corona Virus Disease (Covid-19) Dashboad. https://covid19.who.int/ (Accessed on 4 august 2020) 